\title{
Correction to: Development, validation, and evaluation of an assay for the detection of wood frogs (Rana sylvatica) in environmental DNA
}

\author{
Mark A. Spangler ${ }^{1,2} \cdot$ Falk Huettmann $^{1} \cdot$ Ian C. Herriott ${ }^{3} \cdot$ J. Andrés López $^{2,4}$
}

Published online: 10 November 2017

(C) Springer Science+Business Media B.V., part of Springer Nature 2017

\section{Correction to: Conservation Genet Resour https://doi.org/10.1007/s12686-017-0881-3}

In the original publication, a part of funding information was missed out in the acknowledgement section. The corrected acknowledgement is given below:

Acknowledgements Partial funding was kindly provided by the Alaska Herpetological Society, the University of Alaska Fairbanks Department of Biology and Wildlife (Calvin J. Lensink Graduate Fellowship in Wildlife Biology), and the University of Alaska Fairbanks Institute of Arctic Biology (IAB Summer Graduate Research Fellowship). We thank J. Ream and A. Wenninger for providing assistance in collecting eDNA samples from captive amphibians, G. Zedda for laboratory assistance, and A. Matter for guidance with eDNA techniques. The University of Alaska Museum of the North provided tissue and DNA samples. B. Barnes and K. Kielland assisted with field site selection and access. Two anonymous reviewers and the Springer editorial staff thoughtfully revised this manuscript. We thank the Director's Office of the Institute of Arctic Biology, the office of the Vice Chancellor for Research, and the Resilience and Adaptation Program at the University of Alaska Fairbanks for generously funding publication costs.

The online version of the original article can be found under https://doi.org/10.1007/s12686-017-0881-3.

Mark A. Spangler

maspangler@alaska.edu

1 EWHALE Lab - Institute of Arctic Biology, Biology and Wildlife Department, University of Alaska Fairbanks (UAF), 902 N. Koyukuk Dr., Fairbanks, AK 99775, USA

2 University of Alaska Museum of the North (UAM), 907 Yukon Drive, Fairbanks, AK 99775, USA

3 DNA Core Facility, Institute of Arctic Biology, University of Alaska Fairbanks (UAF), 909 N. Koyukuk Dr., Fairbanks, AK 99775, USA

4 Fisheries Division, College of Fisheries and Ocean Sciences, University of Alaska Fairbanks (UAF), 905 N. Koyukuk Dr., Fairbanks, AK 99775, USA 